\title{
IL DOVERE DI RISERVATEZZA DEI DIPENDENTI DELLE ORGANIZZAZIONI INTERNAZIONALI
}

\author{
O DEVER DE CONFIDENCIALIDADE DOS FUNCIONÁRIOS CIVIS \\ INTERNACIONAIS QUE TRABALHAM PARA ORGANIZAÇÕES \\ INTERNACIONAIS
}

\section{THE DUTY OF CONFIDENTIALITY OF INTERNATIONAL CIVIL SERVANTS WORKING FOR INTERNATIONAL ORGANIZATIONS}

Recebimento: 1 abr. 2021

Aceitação: 1 abr. 2021

\author{
Giulia Torta \\ Ph.D in Diritti Umani \\ Afiliação institucional: Università degli Studi di Palermo - Italia \\ Lattes iD: http://lattes.cnpq.br/6363376177311545 \\ Email: giulia.torta@unipa.it
}

Como citar este artigo / How to cite this article (informe a data atual de acesso / inform the current date of access):

TORTA, Giulia. Il dovere di riservatezza dei dipendenti delle organizzazioni internazionali. Revista da Faculdade de Direito UFPR, Curitiba, v. 65, n. 3, p. 191-214, set./dez. 2020. ISSN 2236-7284. Disponível em: https://revistas.ufpr.br/direito/article/view/80358. Acesso em: $31 \quad$ dez. $2020 . \quad$ DOI: http://dx.doi.org/10.5380/rfdufpr.v65i3.80358.

\begin{abstract}
Nonostante le differenze strutturali e normative che caratterizzano le singole organizzazioni internazionali, la dottrina odierna è unanime nell'affermare la capacità di ciascuna di creare un proprio ordinamento giuridico interno. Il rapporto di impiego nell'ambito di tali organizzazioni replica in modo evidente molte caratteristiche tipiche del rapporto di impiego nell'ambito statale e, sebbene manchi una disciplina uniforme dell'impiego internazionale e ciascuna organizzazione internazionale vanti assoluta autonomia giuridica ed amministrativa, è tuttavia possibile individuare alcuni obblighi e diritti dei funzionari presenti, in modo sostanzialmente omogeneo, nella maggior parte delle organizzazioni. Il paper analizza brevemente, in termini generali, i diritti e i doveri dei funzionari nazionali e internazionali, facendo riferimento agli "Standards of Conducts for the International Civil Service” ed esaminando le normative interne dell'Organizzazione Internazionale del Lavoro (acronimo ILO in inglese) e del World Bank Group (WBG), mettendo in evidenza, in particolare, l'evoluzione che ha caratterizzato il dovere di riservatezza gravante sui dipendenti pubblici, sia a livello nazionale che internazionale. Infatti, a fronte della drastica inversione di tendenza che ha caratterizzato gli ordinamenti degli Stati democratici, il dovere di riservatezza è stato sicuramente riformulato in termini più restrittivi, ma sopravvive e continua a giocare un ruolo importante. Non sembra, perciò, irragionevole affermare che, da un lato, in ragione della sostanziale affinità tra le previsioni normative in tema di dovere di riservatezza, questo possa essere qualificato come un principio generale. Ciò che, invece, rappresenta un importante punto di distinzione tra gli ordinamenti nazionali e internazionali è la ratio che muove i vari legislatori nel disciplinare tale dovere.
\end{abstract}




\title{
PAROLE CHIAVE
}

Organizzazioni internazionali. Pubblico impiego. Funzionari internazionali. Obblighi di condotta. Dovere di riservatezza.

\section{RESUMO}

Apesar das diferenças estruturais e regulatórias que caracterizam as organizações internacionais individuais, a doutrina de hoje é unânime em afirmar a capacidade de cada organização de criar seu próprio sistema jurídico interno. A relação de trabalho dentro dessas organizações reproduz claramente muitas das características da relação de trabalho internas a um Estado e, embora haja uma falta de regras internacionais uniformes sobre o emprego, e cada organização internacional tenha absoluta autonomia jurídica e administrativa, é possível identificar certas obrigações e direitos dos funcionários internacionais que se replicam, de forma ampla e homogênea, na maioria das organizações. O artigo analisa resumidamente, em termos gerais, os direitos e deveres dos funcionários nacionais e internacionais, referindo-se aos "Standards of Conducts for the International Civil Service" e examinando os regulamentos internos da Organização Internacional do Trabalho (ILO, na sigla em inglês) e do World Bank (WBG, em inglês) com foco na evolução do dever de confidencialidade, tanto em nível nacional como internacional. Com efeito, apesar da reversão drástica da tendência que tem caracterizado os Estados democráticos, conduzindo a uma reformulação restritiva do sigilo administrativo e do dever de confidencialidade, este dever ainda está muito vivo e continua a desempenhar um papel importante. Não parece, portanto, desarrazoado afirmar que, dada a substancial afinidade entre as disposições regulamentares em matéria de dever de confidencialidade, esta pode ser qualificada como um princípio geral. Por outro lado, o que representa um importante ponto de distinção entre os ordenamentos jurídicos nacionais e internacionais é a lógica que move os diversos legisladores na regulamentação desse dever.

\section{PALAVRAS-CHAVE}

Organizações internacionais. Emprego público. Funcionário público internacional. Padrões de conduta. Dever de confidencialidade.

\begin{abstract}
Despite the structural and regulatory differences that characterize individual international organizations, today's doctrine is unanimous in affirming the ability of each organization to create its own internal legal system. The employment relationship within these organizations clearly replicates many of the features of the employment relationship within a State and, although there is a lack of uniform international rules on employment and each international organization has absolute legal and administrative autonomy, it is nevertheless possible to identify certain obligations and rights of international civil servants which replicate in most organizations, in a broad homogeneous way. The paper briefly analyzes, in general terms, the rights and duties of national and international civil servants referring to the "Standards of Conducts for the International Civil Service" and examining the internal regulations of the International Labour Organization (ILO) and the World Bank Group (WBG) focusing on the evolution of the duty of confidentiality, both on a national and international level. Indeed, despite the drastic reversal of the trend which has characterized democratic States leading to a restrictive reformulation of administrative secrecy and the duty of confidentiality, this duty is still very much alive and continues to play an important role. Therefore, it does not seem unreasonable to claim that, on the one hand, given the substantial affinity between the regulatory provisions on the duty of confidentiality, this can be classified as a general principle. On the other
\end{abstract}


hand, what represents an important point of distinction between national and international legal systems is the logic that moves the different legislators in the regulation of this duty.

\section{KEYWORDS}

International organizations. Public employment. International civil servant. Standards of conduct. Duty of confidentiality.

\section{INTRODUZIONE}

Il rapporto di pubblico impiego è stato il primo settore a divenire oggetto di normazione specifica negli ordinamenti interni delle organizzazioni internazionali ed è ancora oggi uno strumento utile per comprendere l'evoluzione del diritto amministrativo in un contesto sovranazionale ${ }^{1}$.

La prima affermazione dell'esistenza di una sostanziale analogia tra gli ordinamenti statuali e gli ordinamenti interni alle organizzazioni internazionali, nel particolare ambito dei rapporti di impiego dei funzionari internazionali, risale agli anni sessanta del secolo scorso. In quel periodo, infatti, la dottrina internazionalistica ha sostenuto che la scelta di mantenere la disciplina dei rapporti di impiego in questione completamente estranea alla sfera di competenza degli Stati membri fosse diretta conseguenza di una specifica manifestazione di volontà espressa in tal senso dagli Stati all'atto della costituzione dell'organizzazione ${ }^{2}$. Inoltre, è stato messo in evidenza come tale estraneità all'ordinamento statuale rilevasse giuridicamente sotto due profili distinti: imponendo agli Stati membri delle organizzazioni internazionali, di cui il funzionario era cittadino, l’obbligo di non interferire nell'esercizio dei poteri attribuiti all'ente internazionale (TOSATO, 1967, p. 168 et seq.) e, conseguentemente, prevedendo un riconoscimento dell'esistenza dell'ordinamento interno

1 Si tratta di una materia nella quale storicamente gli Stati non hanno mostrato interesse immediato ad intervenire, nonostante il rapporto si svolga sul loro territorio. Ė importante sottolineare, tuttavia, come la regolamentazione dei funzionari internazionali e la predisposizione di garanzie giurisdizionali a tutela dei loro diritti sia decisamente importante anche direttamente per gli Stati, dal momento che una corretta normazione è presidio dell'indipendenza delle organizzazioni internazionali, a fronte di un rischio, sempre presente, di elevata politicizzazione delle stesse. Come si legge in A. Comba (1967, p. 41-43): "In definitiva sembra di poter affermare che gli Stati hanno un interesse internazionale all'ordinato funzionamento dell'organizzazione [...] occorre infatti valutare l'interesse degli Stati in relazione alla necessità che l'organizzazione goda di un certo grado di indipendenza per raggiungere i fini per i quali è stata istituita. Tale indipendenza trova la sua prima garanzia nell'esistenza di un ordinamento giuridico interno, distinto da quello statuale [...] la delicatezza dei compiti affidati all'organizzazione, inoltre, può imporre anche la tutela giurisdizionale dei diritti dei funzionari in modo da eliminare ogni influenza nazionale, e garantire la libera esplicazione della funzione pubblica internazionale a cui sono stati preposti funzionari stessi. [...] È indubbio che, per le Nazioni Unite e per le istituzioni specializzate, i tribunali amministrativi hanno avuto una funzione notevolmente positiva per il miglior funzionamento dell'organizzazione, per modo che la istituzione di tale organo può assumere anche un contenuto obbligatorio in relazione ai fini istituzionali dell'organizzazione.”

2 Cfr. A. Comba (1967, p. 53): "L'estraneità deriva dall’obbligo assunto dagli Stati membri dell'organizzazione di non disciplinare determinate situazioni per evitare ogni interferenza che possa nuocere al buon funzionamento dell'ente. [...] L'autorità giudiziaria statale, pertanto, non potrebbe giudicare siffatte controversie in quanto non avrebbe il mezzo tecnico per richiamare le norme che regolano il rapporto.” 
dell'organizzazione internazionale, la cui rilevanza, nella sfera dell'ordinamento statuale, era analoga a quella degli ordinamenti giuridici degli altri Stati membri ${ }^{3}$.

Nonostante le differenze strutturali e normative che caratterizzano le singole organizzazioni internazionali, la dottrina odierna, prendendo spunto dalla suindicata linea interpretativa, è comunque ormai unanime nell'affermare la capacità di ciascuna organizzazione internazionale di creare un proprio ordinamento giuridico interno, il quale ha una dignità indipendente da quella del contesto internazionale che ha dato vita all'organizzazione. Tale ordinamento giuridico interno, che deve essere studiato come diritto interno all'ente ${ }^{4}$, disciplina il rapporto di impiego secondo modalità sostanzialmente simili per le caratteristiche giuridiche che le contraddistinguono, a quelle tipiche del rapporto di impiego nell'ordinamento statale ${ }^{5}$.

Le specifiche peculiarità formali ed operative delle organizzazioni internazionali sono, infatti, essenzialmente assimilabili a quelle che si riscontrano nelle amministrazioni nazionali (CASSESE, 1983) e, di conseguenza, le questioni relative alle caratteristiche dell'organizzazione e della governance di tali organizzazioni possono essere analizzate attraverso il patrimonio concettuale del diritto amministrativo e, più in generale, del diritto pubblico nazionale ${ }^{6}$.

In altre parole, ferma restando la necessaria precisazione relativa all'esistenza di differenze anche molto marcate tra le condizioni istituzionali e politiche che tipizzano i vari sistemi nazionali di diritto amministrativo, l'analisi comparata dimostra che i meccanismi del diritto amministrativo preposti alla tutela della trasparenza e della partecipazione alla decisione amministrativa, opportunamente adattati e senza semplicistiche trasposizione nell'organizzazione internazionale ${ }^{7}$, possono indubbiamente contribuire a promuovere una maggiore responsabilità ed un miglior funzionamento degli organismi di regolamentazione globale.

3 Per una ricognizione della normativa attualmente in vigore in materia di pubblico impiego in Italia si rinvia a: A. Foccillo (2018); M. Danza (2017); C. Dell’Aringa e G. Della Rocca (2017); V. Tenore (2017); M. Esposito, V. Luciani, A. Zoppoli, L. Zoppoli (2018).

4 In questo senso: R. Roversi Monaco (1985); L. Oppenheim, (1919); M. O. Hudson (1932); R. Ago (1946); C. Focarelli (2015); M. Starita (2015).

5 Cfr. A. Comba (1967); F. Capotorti (1957); G. Cansacchi (1955); S. Bastid-Basdevant (1957); M. Bedjaoui (1958); K. S. Carlston (1959); J. Lemoine (1962); S. Bastid-Basdevant (1964); J. Lemoine (1968); M. B. Akehurst (1964); R. Silverstein (2017).

6 Così B. Kingsbury e L. Casini (2009, p. 9): “More generally, the practice of IOs has some parallels with earlier national experience concerning such matters as: the proliferation and fragmentation of public bodies; the growing use of private law instruments; the increase in administrative rulemaking (a major feature of the US New Deal, addressed in the Administrative Procedures Act of 1946)”; nello stesso senso si veda anche D. C. Esty (2006) e M. Freedland (2003).

7 Operare una mera trasposizione di istituti dai sistemi giuridici statali alle complesse pratiche delle Organizzazioni Internazionali nella governance globale rischia di essere controproducente ed inutile se non tiene debito conto delle differenze fondamentali tra i due livelli. Cfr. B. Kingsbury e L. Casini (2009, p. 9): “That many important activities of IOs can be regarded as administrative in nature, does not remotely suggest the existence of a general global public administration; there is no global government or global parliament, nor are there real global equivalents of other structures within which national administrations are nested”; si veda in proposito anche D. Sarooshi (2008). 
L'assimilazione tra amministrazioni nazionali ed amministrazioni delle organizzazioni internazionali, però, deve fondarsi, più che sulla comunanza di istituti, sulla condivisione di principi i quali, nonostante la grande varietà di strutture burocratiche di riferimento, devono poter essere utilizzati come criterio unificante ${ }^{8}$. Del resto, come afferma attenta dottrina, “nell'età del diritto amministrativo globale [...] i principi generali del diritto amministrativo divengono mezzi e strumenti della globalizzazione giuridica.” (FLOGAITIS, 2010, p. 94).

Sempre questa linea interpretativa mette in evidenza, inoltre, come il rapporto di impiego nell'ambito delle organizzazioni internazionali sia destinato a replicare in modo evidente molte caratteristiche tipiche del rapporto di impiego nell'ambito statale, quali ad esempio la supremazia giuridica esercitata dal datore di lavoro attraverso l'imposizione di un regolamento unitario (entro certi limiti, unilateralmente variabile) e il rapporto di subordinazione che impronta l'attività del lavoratore al raggiungimento dei fini istituzionali stabiliti dal datore di lavoro. Come rilevato dalla dottrina,

[...] è sufficiente un esame, anche sommario, delle norme che regolano il rapporto giuridico che intercorre tra i funzionari e le organizzazioni internazionali per rilevare la posizione di supremazia dell'organizzazione nei confronti dei suoi dipendenti; in tali rapporti l'elemento contrattuale è limitato quasi esclusivamente alla creazione di un vincolo giuridico, mentre l'insieme dello stato giuridico e la maggior parte dei diritti e degli obblighi viene determinato attraverso disposizioni generali in modo unilaterale. Pertanto, lo statuto e il regolamento del personale sono imposti unilateralmente ai dipendenti senza che essi possano far valere la loro autonomia contrattuale. Le stesse norme, inoltre, possono essere modificate per il miglior funzionamento dell'ente, salvo, entro certi limiti, la tutela dei diritti quesiti. (COMBA, 1967, p. 58-59) .

Quanto poi al vincolo di funzione dei funzionari internazionali, questo è senza dubbio un elemento facilmente riscontrabile nel rapporto di impiego che questi intraprendono con le varie organizzazioni, come ad esempio si evince dal testo degli art. 100 e ss. della Carta delle Nazioni Unite

8 I principi in questione non sono altro che i principi fondamentali individuati dagli studiosi del Global Administrative Law (GAL). "Many GAL principles are actively embraced in particular IOs, and these principles provide a basis for serious discussion and critique in the work of others. Thus, transparency and participation are current preoccupations in relation to the WTO, and due process is intensely debated in relation to sanctions against individuals imposed by the UN Security Council. In some other IO contexts, even consideration of such principles, let alone application of them, is incidental at most. Some of the demands made by reference to GAL principles are unrealistic and potentially counter-productive: for example, too much accountability to the wrong people can be pathological; immense and perhaps insuperable problems arise in adequate representation or direct participation of civil society-type actors and their interests, so that compromises on this are often inescapable; at the global level participatory rights should be accorded considering the different nature of actors involved, which can be either private or public (such as states and domestic administrative agencies) or both; 'notice and comment' requirements for rule-making can facilitate the capture of the process by special interest groups; entitlements to a lengthy hearing and appeal may 'ossifying' procedures and dissuade an underfunded and overstretched agency from acting at all.”: così, B. Kingsbury e L. Casini (2009, p. 10).

9 In tal senso si segnalano anche i contributi di: F. Capotorti (1957), G. Cansacchi (1955); S. Bastid-Basdevant (1957); M. Bedjaoui (1958); K. S. Carlston (1959); J. Lemoine (1962); S. Bastid-Basdevant (1964); J. Lemoine (1968); A. Plantey e F. Loriot (2016); R. Silverstein (2017, p. 375). 
$(1945)^{10}$ ove, se, da un lato, si afferma l'indipendenza assoluta dei funzionari nei confronti dei governi o di ogni altra autorità all’infuori dell’organizzazione, dall'altro lato, si impone agli stessi funzionari l'obbligo di astensione da qualunque comportamento che potrebbe compromettere il ruolo ed il prestigio internazionale dell’organizzazione, nonché l’osservanza di ulteriori obblighi di carattere etico-giuridico, il cui rispetto viene considerato imprescindibile per il corretto esercizio della funzione pubblica internazionale in vista dei fini istituzionali dell'ente.

\section{I DIRITTI E I DOVERI DEI FUNZIONARI INTERNAZIONALI}

Come qualsiasi altro tipo di rapporto di lavoro, anche quello che si instaura tra il lavoratore e l'organizzazione internazionale datrice di lavoro è caratterizzato dalla presenza di una serie di obblighi e di doveri che gravano su entrambe le parti ${ }^{11}$.

Il soggetto privato, infatti, nel momento in cui diviene dipendente di un'organizzazione internazionale, diventa titolare di diritti e doveri specifici che discendono direttamente dal suo inserimento nella struttura dell'amministrazione e lo identificano come soggetto qualificato. È questa la ragione per la quale ai dipendenti pubblici, sia nazionali sia internazionali, è richiesta una cura speciale nell'adempimento delle loro attività, che trova una ragion d'essere nella peculiare relazione che si instaura tra il soggetto privato e l'amministrazione pubblica (MATTARELLA, 2010).

Nonostante l'assenza di una disciplina uniforme dell'impiego internazionale e l'assoluta autonomia giuridica ed amministrativa di ciascuna organizzazione internazionale, è tuttavia possibile individuare alcuni obblighi e diritti dei funzionari che si presentano, in modo sostanzialmente omogeneo, nella maggior parte delle organizzazioni ${ }^{12}$.

10 Carta delle Nazioni Unite (1945), adottata a S. Francisco il 26 giugno 1945, entrata in vigore con il deposito del ventinovesimo strumento di ratifica il 24 ottobre 1945. Ratificata dall’ltalia con legge 17 agosto 1957 n. 848 in Suppl. Ord. G.U. n. 238 del 25 settembre 1957.

11 Il rapporto in questione è volontario (sia la costituzione sia la continuazione del rapporto di lavoro richiedono il perdurare della volontà delle due parti coinvolte nel rapporto contrattuale, ovvero l'amministrazione e il dipendente); strettamente personale (il rapporto di lavoro è costituito "intuitus personae": rilevano le peculiari caratteristiche intellettive e tecniche dello specifico lavoratore e la fiducia che l'amministrazione ripone in questo soggetto); sinallagmatico (il sinallagma è il legame tra prestazione e controprestazione che caratterizza quei contratti nei quali gli obblighi e i diritti reciproci sono collegati da un rapporto di interdipendenza; nel caso del pubblico impiego, gli elementi che compongono il sinallagma sono, da un lato, la prestazione lavorativa del dipendente, e dall'altro, la retribuzione da parte della amministrazione); generalmente contraddistinto dalla presenza di un vincolo di subordinazione; idoneo ad incardinare un soggetto privato nell'organizzazione dell'amministrazione che lo ha selezionato. Per un approfondimento generale sul pubblico impiego si vedano, tra gli altri: V. Cerulli Irelli (2016); E. Casetta (2016); G. Corso, (2017); F. Caringella (2016); R. Chieppa e R. Giovagnoli (2018); M. Clarich (2017); R. Garofoli e G. Ferrari (2018); F. G. Scoca (2017).

12 Sono state prese in considerazione le Organizzazioni Internazionali che rientrano nel sistema dell’Organizzazione delle Nazioni Unite, ma discipline simili sono state adottate anche all'OECD, alla NATO, all'UEO, all'ESA, al CoE, all'ECMWF e alla WB. 
In proposito, la International Civil Service Commission ${ }^{13}$ è stata incaricata di operare una prima cristallizzazione dei diritti e soprattutto dei doveri dei funzionari internazionali nel 1954, quando è stata adottata la prima versione degli "Standards of Conducts for the International Civil Service” (2013), successivamente rielaborata nel 2001 e, da ultimo, nel $2013^{14}$.

Il lavoro dell’International Civil Service Commission muove da una concezione del personale amministrativo internazionale quale strumento per tradurre gli ideali che hanno portato alla nascita delle organizzazioni internazionali in realtà concrete. Dunque, prendendo spunto dalle grandi tradizioni delle pubbliche amministrazioni degli Stati membri e dai principi fondamentali che le contraddistinguono (ad esempio, imparzialità ${ }^{15}$ ed indipendenza ${ }^{16}$ ), la Commissione afferma che i funzionari internazionali sono chiamati a rispondere ad una

13 L'International Civil Service Commission (ICSC) è un organismo di esperti indipendenti istituito dall'Assemblea generale delle Nazioni Unite. Il suo mandato è regolare e coordinare le condizioni di servizio del personale nel sistema comune delle Nazioni Unite, promuovendo e mantenendo gli standard più elevati. La Commissione è composta da quindici membri che servono a titolo personale e sono nominati dall'Assemblea generale per un periodo di quattro anni, con il dovuto riguardo per un'ampia rappresentanza geografica. Il presidente e il vicepresidente sono membri a tempo pieno e hanno sede a New York. La Commissione completa si riunisce due volte all'anno.

14 L'ultima edizione è stata approvata dall'Assemblea generale delle Nazioni Unite con la Risoluzione 67/257 del luglio 2013. Come si legge nella prefazione: "Over the years, the relationship between staff members and their organizations had evolved. Most organizations had undergone significant reforms and moved away from rules- based to values and results-based systems with increased decentralization and greater responsibilities to lower level management. Those developments demanded clearer standards in relation to contacts outside the common system and more transparent accountability systems. A renewed interest in the subject on the part of national civil services and the private sector in responding to new ethical challenges was a further stimulus to this revised text. The title, Standards of Conduct for the International Civil Service, remains as self-explanatory now as it was in 1954. Like the versions before them, these revised Standards are intended as a behavioral and ethical guide. They exist to inform, but also to inspire us and, when needed, to provide explanations. They reflect the philosophical underpinnings of the international civil service and inform its conscience. We trust that like the previous version, the present Standards become an indispensable part of the culture and heritage of the organizations and are of similarly enduring quality.” (UNITED NATIONS, 2013).

15 Par. 8 e 9 Standards of Conduct for the International Civil Service (UNITED NATIONS, 2013): "8. If the impartiality of the international civil service is to be maintained, international civil servants must remain independent of any authority outside their organization; their conduct must reflect that independence. In keeping with their oath of office, they should not seek nor should they accept instructions from any Government, person or entity external to the organization. It cannot be too strongly stressed that international civil servants are not, in any sense, representatives of Governments or other entities, nor are they proponents of their policies. This applies equally to those on secondment from Governments and to those whose services have been made available from elsewhere. International civil servants should be constantly aware that, through their allegiance to the Charter and the corresponding instruments of each organization, member States and their representatives are committed to respect their independent status. 9. Impartiality implies tolerance and restraint, particularly in dealing with political or religious convictions. While their personal views remain inviolate, international civil servants do not have the freedom of private persons to take sides or to express their convictions publicly on controversial matters, either individually or as members of a group, irrespective of the medium used. This can mean that, in certain situations, personal views should be expressed only with tact and discretion.”

16 Par. 11 e 12 Standards of Conduct for the International Civil Service (UNITED NATIONS, 2013): “11. The independence of the international civil service does not conflict with, or obscure, the fact that it is the member States that collectively make-up — in some cases with other constituents — the organization. Conduct that furthers good relations with individual member States and that contributes to their trust and confidence in the organizations' secretariat strengthens the organizations and promotes their interest. 12. International civil servants who are responsible for projects in particular countries or regions may be called upon to exercise special care in maintaining 
[...] special calling: to serve the ideals of peace, respect for fundamental rights, economic and social progress, and international cooperation. It is therefore incumbent on international civil servants to adhere to the highest standards of conduct; for, ultimately, it is the international civil service that will enable the United Nations system to bring about a just and peaceful world. (UNITED NATIONS, 2013, p. 3).

In altre parole, la Commissione riconosce il ruolo fondamentale dei valori sanciti dalle organizzazioni delle Nazioni Unite ${ }^{17}$ nel corretto funzionamento delle varie organizzazioni che ad essa sono collegate, dal momento che tali valori devono orientare tutte le azioni dei singoli membri dello staff: anzi, è proprio la lealtà a questa visione ${ }^{18}$ che garantisce l'integrità dell'intero sistema internazionale ${ }^{19}$.

In base agli Standards of Conducts for the International Civil Service (UNITED NATIONS, 2013): è possibile affermare che esiste un nocciolo duro di diritti che spettano sicuramente al funzionario internazionale: il diritto ad avere una retribuzione commisurata alla qualifica ${ }^{20}$; il diritto alla carriera $^{21}$; il diritto all'indennità di fine rapporto ${ }^{22}$; il diritto alla pensione; il diritto all'aumento periodico dello stipendio; il diritto all'assicurazione sociale; il diritto ad eventuali integrazioni salariali per il mantenimento e lo studio dei figli; il diritto alle indennità speciali collegate alle

their independence. At times they might receive instructions from the host country, but this should not compromise their independence. If at any time they consider that such instructions threaten their independence, they must consult their supervisors."

17 In particolare, della tutela dei diritti umani fondamentali, della giustizia sociale, della dignità e del valore della persona umana, nonché il rispetto degli uguali diritti degli uomini e delle donne e di nazioni grandi e piccole. Il par. 6 degli Standards of Conduct for the International Civil Service (UNITED NATIONS, 2013), afferma, in proposito, che: “6. Tolerance and understanding are basic human values. They are essential for international civil servants, who must respect all persons equally, without any distinction whatsoever. This respect fosters a climate and a working environment sensitive to the needs of all. To achieve this in a multicultural setting calls for a positive affirmation going well beyond passive acceptance.” E il paragrafo 15 afferma anche che: "15. Freedom from discrimination is a basic human right. International civil servants are expected to respect the dignity, worth and equality of all people without any distinction whatsoever. Assumptions based on stereotypes must be assiduously avoided. One of the main tenets of the Charter is the equality of men and women, and organizations should therefore do their utmost to promote gender equality."

18 Par. 7 Standards of Conduct for the International Civil Service (UNITED NATIONS, 2013): “International loyalty means loyalty to the whole United Nations system and not only to the organization for which one works; international civil servants have an obligation to understand and exemplify this wider loyalty."

19 Par. 5 Standards of Conduct for the International Civil Service (UNITED NATIONS, 2013): “The concept of integrity enshrined in the Charter of the United Nations embraces all aspects of an international civil servant's behaviour, including such qualities as honesty, truthfulness, impartiality and incorruptibility. These qualities are as basic as those of competence and efficiency, also enshrined in the Charter."

20 Va richiamato, in proposito, il principio "Noblemaire”, affermato da Georges Noblemaire nel 1921 nel suo documento "Organisation of the Secretariat and of the International Labour Office. Report of the Commission of experts appointed in accordance with the resolution adopted by the League of Nations at its meeting of December 17th, 1920". In base al principio in questione, i salari devono essere fissati ad un livello superiore o almeno equivalente alla retribuzione più elevata riconosciuta al personale impiegato presso le amministrazioni nazionali (FEDERATION OF INTERNATIONAL CIVIL SERVANTS’ ASSOCIATIONS, 2004, p. 1-2).

21 "Ossia il diritto ad ottenere il conferimento di funzioni gerarchicamente superiori ed il corrispondente emolumento" (GALLO, 2012, p. 290).

22 In caso di licenziamento. Nel caso di licenziamento illegittimo il funzionario vanta anche un diritto al risarcimento del danno. 
particolari condizioni dell'attività svolta; il diritto al rimborso per le missioni all'estero; il congedo per maternità; il diritto di associazione; il diritto di aderire a sindacati; il diritto di eleggere i propri rappresentanti.

Nonostante l'elencazione sia breve e non esaustiva, è evidente come questo nucleo di diritti rispecchia quelli previsti nei contratti di lavoro nazionali e nelle discipline statali. Peraltro, tale similitudine si riscontra anche sotto il profilo dei doveri che gravano sui funzionari internazionali: il dovere di perseguire, in modo continuativo ed esclusivo, i fini e gli interessi dell'ente di appartenenza; il dovere di seguire le direttive dei superiori gerarchici; il dovere di indipendenza; il dovere di imparzialità; il dovere di fedeltà; il dovere di mantenere il segreto d'ufficio; il dovere di riservatezza.

\subsection{IL DOVERE DI RISERVATEZZA}

Particolare attenzione deve prestarsi al dovere di riservatezza gravante sui dipendenti pubblici poiché la riservatezza è un concetto strettamente collegato a quello di segreto amministrativo, ma caratterizzato da un respiro più ampio.

Esso consiste, oltre che nel dovere di rispettare il segreto di ufficio ${ }^{23}$, anche nel più generale dovere, gravante sui dipendenti, di utilizzare le informazioni amministrative senza trarne alcun profitto personale; di trattare le informazioni, di cui ciascun dipendente entra in possesso in ragione del suo rapporto privilegiato con l'amministrazione, in modo sicuro e di renderle pubbliche solo nei tempi e nei modi previsti dalla legge; di evitare ogni dichiarazione pubblica concernente la sua attività lavorativa, nonché ogni dichiarazione che possa arrecare danno al prestigio ed all'immagine dell'autorità; di richiedere l'autorizzazione preventiva sia per poter intrattenere rapporti con la stampa, sia per poter partecipare a convegni od incontri attinenti a materie di specifico interesse per l'attività di ufficio, in occasione dei quali questi non potrà, comunque, assumere iniziative od esprimere opinioni che siano in contrasto con le direttive impartite dall'amministrazione presso la quale svolge la propria attività lavorativa.

Un dovere così configurato, pur avendo un effetto limitativo sulla trasmissione delle informazioni amministrative a soggetti esterni all'amministrazione e sulla libertà di ciascun funzionario, non deve tuttavia essere inteso in termini contrastanti rispetto ai principi di imparzialità, buon andamento e trasparenza. Infatti, il divieto di pubblicare o divulgare notizie non ostensibili al

23 Che si esplica, in concreto, nel divieto previsto dalla legge di comunicare, all'esterno dell'amministrazione, notizie o informazioni di cui essi siano venuti a conoscenza nell'esercizio delle loro funzioni, ovvero che riguardino l'attività amministrativa in corso di svolgimento o già conclusa. 
pubblico si ricollega, da un lato, alla mancanza di legittimazione del soggetto privato ad accedere ad una data informazione e, dall'altro, all'assenza di un titolo giuridico che possa autorizzare il dipendente a rendere conoscibili all'esterno dell'amministrazione informazioni al di fuori dei tempi e dei modi previsti dalla legge. Il dovere di riservatezza, dunque, deve essere inteso come una conseguenza di quella "garanzia di mantenimento della compagine dell'apparato che esige una precisa distribuzione di compiti” (ABBAMONTE, 1991, p. 21) ${ }^{24}$.

Allo stesso tempo, il sacrificio imposto alla libertà dei funzionari trova una propria giustificazione nel dovere di fedeltà dei dipendenti all'organizzazione, che li vincola a rispettare le norme interne dell'organizzazione (incluse quelle sul diritto di accesso, quelle relative al codice disciplinare degli impiegati, e quelle preposte alla garanzia dell'efficienza dell'azione amministrativa per il corretto, adeguato, ordinato e tempestivo disbrigo degli affari amministrativi).

\subsection{IL PRINCIPIO DI TRASPARENZA}

Il dovere di riservatezza, così come configurato, richiede necessariamente un riferimento al principio di trasparenza amministrativa, rispetto al quale sembra apparentemente porsi in antitesi.

Il principio di trasparenza amministrativa è qualificabile come un vero e proprio principio fondamentale dello Stato di diritto, inestricabilmente connesso al principio democratico (BOBBIO, 1980, p. 181 et seq.), e la cui progressiva affermazione ha determinato una significativa evoluzione in senso orizzontale e paritario del rapporto tra pubblica amministrazione e cittadini (BENVENUTI, 1994). In quest'ottica, infatti, il principio di trasparenza amministrativa è considerato presupposto necessario per l'esercizio di una partecipazione effettiva e consapevole dei cittadini alla vita dell'amministrazione ed è altresì essenziale per rendere individuabili le sedi e le modalità con cui avviene l'esercizio del potere amministrativo. Peraltro, il principio di trasparenza è anche un valido strumento di legittimazione istituzionale dell'amministrazione di fronte ai cittadini, che possono comprendere le motivazioni e le finalità delle azioni dell'amministrazione e verificare il rispetto dei principi di imparzialità e buon andamento nell'interesse della comunità.

\footnotetext{
24 Sempre Abbamonte chiarisce, poi, nello stesso scritto, che "sono esigenze di ordine e di funzionalità degli apparati che portano a riaffermare il dovere di fedeltà; nello stesso tempo, la caratterizzazione degli apparati nel senso che siano idonei ad esprimere uno stato democratico, richiede l'elaborazione di leggi sulle competenze, forme e procedimenti, adatte a rispondere alla domanda di trasparenza rivolta all'apparato nel suo complesso, salvo, ove ricorra, il diritto speciale delle situazioni di necessità che giustifica il segreto” (ABBAMONTE, 1991, p. 21).
} 
In Italia ${ }^{25}$, come nella maggior parte dei sistemi giuridici occidentali moderni ${ }^{26}$, pur se collegati a tradizioni giuridiche differenti, l'agire amministrativo è ormai, per regola generale, trasparente e solo in casi eccezionali segreto. Anche in ambito internazionale ha trovato riscontro l'affermazione del principio di trasparenza amministrativa ${ }^{27}$, intesa come accessibilità delle informazioni concernenti l'organizzazione e l'attività delle pubbliche amministrazioni, allo scopo di favorire forme diffuse di controllo sul perseguimento delle funzioni istituzionali e sull'utilizzo delle risorse pubbliche.

Sarebbe, tuttavia, scorretto affermare che il segreto amministrativo ed il dovere di riservatezza siano quasi del tutto scomparsi. A fronte della drastica inversione di tendenza che ha caratterizzato gli ordinamenti degli Stati democratici, infatti, il segreto amministrativo ed il dovere di riservatezza sono stati sicuramente riformulati in termini più restrittivi, ma sopravvivono e continuano a giocare un ruolo importante nei sistemi amministrativi nazionali. Invero, come sottolinea attenta dottrina,

[...] una secretazione prevista o comunque autorizzata da norme di legge, congruamente procedimentalizzata dalle medesime e che risponda ad «interessi tutelati dall'ordinamento» (secondo la formula usata da Arena, che utilizza per tale ipotesi il termine «segreto reale») e che sia funzionale ad interessi costituzionalmente protetti (come ulteriormente specificato da Merusi, da Loiodice e da ultimo da Villata), non si mostra in alcun modo incompatibile con la trasparenza, proprio perché del «segreto» risultano nella specie chiare l'esistenza e le modalità dell'applicazione ed univoche e coerenti le finalità (MARRAMA, 1991, p. 59) ${ }^{28}$.

Peraltro, come sottolineavano gli interpreti già nell’ultima decade del secolo scorso,

[...] la trasparenza è una parola che va di moda. Va di moda in politica fino dal tempo dello scandalo Watergate. Con la Glasnost di Gorbaciov è diventata un simbolo denso di enormi valori civili e rivoluzionari. [...] La trasparenza è sinonimo di verità, di chiarezza, di onestà. È il contrario della menzogna, della falsità, dell'inganno. La trasparenza è stata definita uno dei miti sociopolitici del nostro tempo. (QUADRI, 1991, p. 23).

25 Il D.P.R. n. 3/1957 (GU n.22 del 25-01-1957 - Suppl. Ordinario n. 220) sanciva, nella versione originale, un dovere generale di riservatezza gravante sui pubblici dipendenti (art. 15) la cui violazione comportava una misura disciplinare (artt. 80, c. 3 lett. g e 81, c. 2, lett. d). Il testo dell'art. 15 è stato modificato dalla l. n. 241/1990 (GU n.192 del 18-081990) così da introdurre nell'ordinamento norme sul diritto di accesso (art. 7 e 10). Più di recente, le coordinate entro le quali il dipendente pubblico deve inquadrare il proprio agire sono state cristallizzate nel codice di comportamento dei dipendenti pubblici, adottato con il decreto del Presidente della Repubblica n. 62/2013 (GU Serie Generale n.129 del 04-06-2013), successivamente integrato dalle modifiche introdotte dalle singole amministrazioni.

26 A tal riguardo: S. Battini (2006); C. Hood e D. Heald (2006); A. Meijer (2009); D. Lathrop e L. Ruma (2010); A. Meijer (2013); M. V. Cucciniello, G. A. Porumbescu e S. Grimmelikhuijsen (2017); A. Meijer, P. ‘t Hart e B. Worthy (2018); G. Gardini (2018); O. Mir Puigpelat (2019); Pintos Santiago (2017); D. Curtin e J. Mendes (2011); M. Pasquier (2013).

27 Sul principio di trasparenza si vedano, tra gli altri: G. Arena (2006); G. Arena, G. Corso, G. Gardini, C. Marzuoli e F. Merloni (2008); M. R. Spasiano (2011); F. Manganaro (2012); L. Califano e C. Colapietro (2014); M. C. Cavallaro (2015); G. Avanzini e G. Matucci (2016); A. Lazzaro (2017); A. Simonati (2018); A. Contieri (2018).

28 Si vedano anche: A. Anzon (2010); F. Costantino (2010). 
La trasparenza corretta, dunque, non coincide con quella sfera di conoscibilità che viene garantita nei confronti di chiunque, in qualunque momento e in modo caotico, ma è un assetto organizzativo e funzionale del tutto concreto, che si realizza in modo ordinato e coerente e permette davvero ai cittadini di vedere attraverso la "casa di vetro", comprenderne il funzionamento, ed apprezzare il risultato dell'azione amministrativa. Quindi, tutto ciò può realizzarsi anche e soprattutto attraverso il rispetto del dovere di riservatezza da parte dei dipendenti pubblici ${ }^{29}$.

\subsection{IL DOVERE DI RISERVATEZZA DEI FUNZIONARI INTERNAZIONALI COME PRINCIPIO GENERALE DELL'AGIRE AMMINISTRATIVO IN AMBITO SOVRANAZIONALE}

In linea generale, accettando la nomina, i funzionari internazionali si impegnano a svolgere le loro funzioni e a regolare la loro condotta tenendo conto solo ed unicamente degli interessi dell’organizzazione presso la quale lavorano; inoltre, riconoscono di essere soggetti all’autorità del Direttore Generale, nei cui confronti sono responsabili per le azioni compiute nell'esercizio delle loro funzioni ${ }^{30}$.

Presso l’Organizzazione Internazionale del Lavoro (ILO), ad esempio, a fronte di quattro valori cardine dell’organizzazione amministrativa (integrità ${ }^{31}$, professionalità ${ }^{32}$, rispetto per la

29 Come afferma M. Raveraira (1999, p. 18): “[Il villaggio globale] sembrerebbe tendere a modificare la relazione tra pubblico e privato e la relazione tra privati riconducendole tutte alla regola della pubblicità. Esso sembrerebbe pertanto non tollerare ambiti «segreti»; sembrerebbe non ammettere, né in fatto, né in diritto, che la conoscenza di uno o di pochi sia da questi negata agli altri. Senonché, per quanto fondante, per quanto cardine, la massima libertà di circolazione delle informazioni, ove riguardata nella sua assolutezza, finisce, come in una galleria degli specchi, per rifrangersi in immagini via via deformate sino a riflettersi nel proprio contrario. Per uno dei tanti paradossi determinati dalle spinte di segno contrapposto più che mai presenti nelle società contemporanee, di là dall'assunto, la libertà di circolazione [delle informazioni] non solo non esclude il segreto ma finisce addirittura per indurne l'ampliamento.”

30 Quando prendono servizio, i funzionari internazionali pronunciano un giuramento di lealtà. Ad esempio, ai sensi dell'art. 1.4, par. 3, cap. I dello Statuto del personale dell’ILO, per i funzionari dell'Organizzazione Internazionale del Lavoro il giuramento è il seguente: "I solemnly undertake to exercise in all loyalty, discretion and conscience the functions that have been entrusted to me as an official of the International Labour Office, to discharge these functions and regulate my conduct with the interests of the International Labour Organization alone in view, and not to seek or accept instructions in regard to the performance of my duties from any government or other authority external to the International Labour Office” (INTERNATIONAL LABOUR OFFICE, 2020).

31 L'integrità si concretizza, sostanzialmente, in una serie di comportamenti probi che includono: il farsi portatore dei valori dell'ILO e delle Nazioni Unite nelle attività quotidiane; il non porre in essere atti per guadagno personale; il saper resistere alla pressione politica tipica del processo decisionale; il prendere decisioni nell’interesse dell'Organizzazione, anche se impopolari; il prendere azioni tempestive e pertinenti in caso di comportamento non professionale o non etico.

32 La professionalità si concretizza, sostanzialmente, in una serie di comportamenti che includono: il mostrare orgoglio per il lavoro svolto e per i risultati raggiunti; il dimostrarsi professionale e competente, nonché padrone della materia; l'essere coscienzioso ed efficiente nel rispettare gli impegni; il rispettare le scadenze e l'ottenere i risultati programmati, il dimostrare persistenza di fronte a problemi o sfide difficili, rimanendo calmo in situazioni stressanti. 
diversità $^{33}$, lavoro di squadra ${ }^{34}$ ), che devono riflettersi nelle azioni quotidiane dello staff, sono individuati dieci principi generali di condotta, pubblicizzati dall'opuscolo sui principi della condotta per il personale dell'ILO elaborato dall'Ethic Office; essi vincolano l'attività dei funzionari, indipendentemente da fatto che questa sia posta in essere all'interno dell'Organizzazione o si realizzi all'esterno della stessa o al di fuori degli orari di lavoro ${ }^{35}$. Per gli aspetti che qui ci interessano vengono in particolare rilievo i principi tre e sei.

Il terzo principio ${ }^{36}$ impone ai membri del personale di impegnarsi a svolgere le attività ufficiali e quelle private in modo da evitare conflitti di interesse, così da preservare l'immagine dell'Organizzazione e la fiducia che i soggetti terzi hanno nella stessa. Tra i vari comportamenti che il funzionario dovrebbe volontariamente porre in essere, in base a questo principio, rientrano, quindi, quello di non accettare istruzioni da alcun governo, persona o entità; quello di astenersi dall'esprimere pubblicamente condanne su questioni controverse; quello di esprimere le proprie opinioni personali e politiche con tatto e riservatezza.

Il sesto principio ${ }^{37}$ pone l'accento sulla necessità di salvaguardare e utilizzare in modo responsabile le informazioni e le risorse cui i funzionari, in ragione del loro impiego presso l’ILO, possono entrare in possesso. A tal proposito l'articolo 1.3 del capitolo I dello Statuto del personale dell’ILO (2020) chiarisce che i funzionari devono esercitare la massima discrezione in tutte le questioni ufficiali e sono tenuti a prestare la massima attenzione nel non divulgare, senza previa autorizzazione, informazioni inedite a loro note in ragione della loro posizione ufficiale. I funzionari, infatti, non possono pubblicare, far pubblicare o assistere alla pubblicazione di alcun materiale relativo all’Organizzazione Internazionale del Lavoro o fornire un indirizzo pubblico relativo all’Organizzazione, salvo nel corso delle loro funzioni o con l'autorizzazione del Direttore

33 Il rispetto per la diversità si concretizza, sostanzialmente, in una serie di comportamenti che includono: la capacità di essere efficaci lavorando con persone di ogni provenienza; il saper trattare tutte le persone con dignità e rispetto; il trattare uomini e donne allo stesso modo; la capacità di rendersi consapevole e superare i propri pregiudizi e comportamenti sbagliati per evitare risposte stereotipate; il non discriminare mai nessun individuo o gruppo.

34 Il saper fare lavoro di squadra si concretizza, sostanzialmente, in una serie di comportamenti che includono: la collaborazione attiva con i colleghi per il raggiungimento degli obiettivi prefissati; la valorizzazione delle idee e delle competenze degli altri membri della squadra; la disponibilità ad imparare dagli altri; il rispetto per l'agenda della squadra che deve essere anteposta a quella personale di ciascun singolo membro della stessa; il supportare e l'agire in accordo con le decisioni di gruppo anche quando la posizione personale sia diversa; il condividere il credito per i risultati della squadra e l'accettare la responsabilità congiunta per le carenze eventualmente evidenziate.

35 Art. 1.2 cap. I Statuto del personale dell’ILO: "Officials shall conduct themselves at all times in a manner befitting their status as international civil servants” (INTERNATIONAL LABOUR OFFICE, 2020).

36 Terzo principio: "[...] commit to performing official duties and conducting private affairs in a manner that avoids conflicts of interest to ensure the enhancement and preservation of public confidence in the ILO”. (INTERNATIONAL LABOUR OFFICE, 2009).

37 Sesto principio: “[...] safeguard and make responsible use of the information and resources to which [staff members] have access by reason of [their] employment with ILO” (INTERNATIONAL LABOUR OFFICE, 2009). 
Generale $^{38}$. Quanto, infine, alle relazioni con i media, sempre l'opuscolo chiarisce che i funzionari che interagiscono con la stampa devono sempre tenere presente il loro ruolo istituzionale, sicché devono evitare di fare riferimenti personali, di divulgare versioni non ufficiali e di utilizzare i media per meri interessi personali.

Una serie di norme dal contenuto simile può essere rinvenuta anche nella disciplina degli standard di condotta dei dipendenti del World Bank Group (WBG).

Per quanto attiene ai doveri dei funzionari internazionali alle dipendenze del WBG, il principio 3 della policy del $1983^{39}$ afferma, in termini generali, la necessità che i funzionari siano consapevoli della natura sensibile e riservata di gran parte del loro lavoro, che richiede un alto grado di integrità e attenzione per gli interessi delle Organizzazioni ${ }^{40}$, ed impone, altresì, l'obbligo di evitare situazioni ed attività che potrebbero riflettersi negativamente sulle Organizzazioni datrici di lavoro, compromettere le loro operazioni o condurre a conflitti di interessi reali o apparenti.

In modo più specifico, il principio 3 identifica come obbligazioni generali gravanti sui membri del personale: il dovere di comportarsi sempre in un modo che si addice al loro status di dipendenti di un’organizzazione internazionale; il dovere di evitare qualsiasi azione e, in particolare, qualsiasi dichiarazione pubblica o attività lucrativa personale che possa riflettersi negativamente 0 sfavorevolmente sul loro status o sull'integrità, l'indipendenza e l'imparzialità richieste da tale status; il dovere di osservare la massima discrezione in merito a tutte le questioni relative alle Organizzazioni sia mentre sono membri dello staff sia dopo che il loro servizio con le Organizzazioni è terminato, astenendosi dal diffondere in modo improprio, diretto o indiretto, informazioni relative all'attività del WBG.

38 Art. 1.3 capitolo I Statuto del personale dell’ILO: “(a) Officials shall exercise the utmost discretion in all matters of official business. They shall not, except in the performance of their duties or by authorization of the Director-General, communicate to any person unpublished information known to them by reason of their official position. These obligations shall continue to bind officials after they leave the service. (b) Officials shall not publish, cause to be published, or assist in the publication of any material relating to the International Labour Organization or deliver a public address relating to the Organization, except in the course of their duties or by authorization of the DirectorGeneral.” (INTERNATIONAL LABOUR OFFICE, 2020). L'opuscolo sui principi di condotta per il personale dell'ILO, elaborato dall'Ethic Officer afferma, inoltre, che devono essere mantenute riservate, salvo che non siano già pubbliche o la loro pubblicazione non venga autorizzata, tutte le informazioni relative ai colleghi, tutte le informazioni relative ai processi sul posto di lavoro ed ai vari progetti avviati, nonché tutte le altre informazioni relative al posto di lavoro.

39 Attraverso l'individuazione di principi generali, la definizione delle condizioni generali di impiego nell’Organizzazione, nonché l’individuazione dei doveri e degli obblighi delle Organizzazioni e dei membri dello staff, la policy in questione è infatti il baluardo che ispira e garantisce la corretta definizione delle politiche generali di organizzazione e gestione dello staff adottate dal Presidente del WBG.

40 Circa l'obbligo di non abusare della propria posizione per ottenere vantaggi o guadagni personali, enucleato dal principio 3, è utile fare riferimento a WBAT 18 luglio 2008 n. 388 e WBAT 25 maggio 2011 n. 451. 
Il dettato del principio 3 è poi confluito, più di recente, nella staff rule 3.01, rubricata "standards of professional conduct", che ne approfondisce ulteriormente il dettato ed enuclea gli standard di condotta ed i doveri fondamentali dei funzionari del WBG, cristallizzandoli nel corpo normativo delle regole del personale.

In questa nuova normativa tutti i principali aspetti del dovere di riservatezza sono riproposti ed immancabilmente viene affermato, in termini chiari, sia il dovere di non divulgare informazioni senza aver previamente ricevuto un’apposita autorizzazione scritta da parte di un dirigente ${ }^{41}$, sia il dovere di non rendere dichiarazioni pubbliche in mancanza di un'apposita autorizzazione scritta da parte dell’Organizzazione ${ }^{42}$.

\section{LA RATIO DEL DOVERE DI RISERVATEZZA È DAVVERO SEMPRE LA STESSA?}

Com'è evidente da questa breve ricostruzione, il dovere di riservatezza dei pubblici dipendenti è tratteggiato in termini analoghi in sistemi giuridici che presentano tra loro alcune differenze, a volte anche marcate, come possono essere appunto quelli statali e quelli di due grandi organizzazioni internazionali, come il World Bank Group e l’Organizzazione Internazionale del Lavoro.

Non sembra, perciò, irragionevole affermare che, in ragione della sostanziale affinità tra le previsioni normative in tema di dovere di riservatezza dei dipendenti pubblici, tale dovere possa essere qualificato come un principio generale, destinato a regolare la condotta dei dipendenti pubblici in tutti gli ordinamenti, indipendentemente dalla natura pubblicistica o privatistica del rapporto.

41 Sezione III staff rule 3.01: "5.01 Staff members and former staff members in possession of non-public information obtained in the course of Bank Group employment shall not, without written authorization from a senior manager, disclose to any third party for any reason or otherwise use such information in furtherance of a private interest or the private interest of any other person or entity. These obligations continue after separation from Bank Group service. 'Non-public information' is defined as information generated by the Bank Group that has not been approved for release outside the Bank Group in accordance with the Bank Group’s Rules. 5.02 Staff members may be required to sign agreements with governments, and other entities or persons, for the protection of the secrecy of proprietary information made known to them by reason of their Bank Group employment.” (WORLD BANK GROUP, 2009).

42 Sezione III staff rule 3.01: “7.01 Except as provided in this Rule, Staff members may not testify in person or in writing before national or other legislatures without written authorization from the staff member's Vice President, in consultation with the General Counsel of the applicable Bank Group organization and the Vice President, External Affairs. Such authorization may be granted in exceptional circumstances of institutional significance, but only so long as the testimony concerns factual matters based on the Bank Group's work, is not compulsory, is permissible under the Bank Group organization's disclosure policy, and has been requested or endorsed by the executive branch of the government concerned. The authorization may limit the manner or scope of testimony. 7.02 Public statements, other than testimony before national or other legislatures, on issues which concern Bank Group policies and activities or which may generally affect the Bank Group’s public image or relationship with member governments must be cleared in accordance with the procedures set out in Administrative Manual Statement 14.20, 'Public Statements of Staff Members.’” (WORLD BANK GROUP, 2009). 
Ciò che, invece, rappresenta un importante punto di distinzione tra gli ordinamenti considerati è la ratio che muove i vari legislatori nel disciplinare, con le modalità appena descritte, gli obblighi di riservatezza dei dipendenti pubblici.

Nel sistema giuridico italiano, per esempio, il principio di trasparenza è stato al centro del dibattito della dottrina sin dagli anni 90 ed è stato riconosciuto in modo sempre più esteso dalla legislazione, fino alla recente adozione del FOIA ${ }^{43}$, mentre il dovere di riservatezza ed il segreto di ufficio si sono progressivamente ridimensionati e spostati sullo sfondo del dibattito, rimanendo nell'ordinamento come strumenti funzionali a rendere più chiare e sicure le informazioni che vengono diffuse. Nel far ciò, la ratio che ha orientato le scelte del legislatore italiano è stata improntata, in via prioritaria, all'implementazione del principio democratico (ovvero la partecipazione dei privati all'attività amministrativa) e dei principi di buon andamento e di imparzialità. Come sottolineato dalla dottrina, infatti,

[...] il riconoscimento del diritto di accedere alle informazioni amministrative è uno strumento indispensabile per permettere a giornalisti, accademici, gruppi di interesse e cittadini in generale di verificare la correttezza delle decisioni pubbliche e di condividere quelle informazioni con la collettività. Per questo, il diritto in questione è entrato a far parte del patrimonio costituzionale di gran parte delle democrazie. E per questo anche gli ordinamenti nei quali l'istituto sembra aver prodotto risultati meno convincenti non possono rinunciarvi. «Hard to resist», dunque, ma anche «hard to escape». [...] Per garantire il buono stato di una democrazia, è essenziale poter contare su strumenti che arricchiscano il patrimonio di conoscenze individuali e collettive, tanto più in un'epoca di “post-verità”, nella quale la disponibilità di informazioni affidabili può contribuire a salvare la democrazia dai suoi demoni, fungendo da antidoto alla tendenza (anche della politica) a manipolare i dati di realtà. (SAVINO, 2019, p. 453).

Nel caso delle organizzazioni internazionali, invece, più che il principio democratico o i principi di buon andamento e imparzialità, l'obiettivo che viene perseguito è quello di tutelare e promuovere l'immagine e la credibilità internazionale dell'organizzazione. La c.d. accountability ${ }^{44}$, infatti, è strettamente connessa al principio di trasparenza amministrativa ed è il risultato del delicato bilanciamento tra questo principio ed il dovere di riservatezza gravante sui dipendenti pubblici.

43 Il FOIA (Freedom of Information Act), introdotto con d. lgs. n. 97 del 2016 (GU Serie Generale n.132 del 08-062016), è parte integrante del processo di riforma della pubblica amministrazione, definito dalla legge 7 agosto 2015 , n. 124.

44 Cfr. A. E. Pereira, R. R. Horochovski, M. Mattos de Almeida Cruz e N. Rodrigues (2017, p. 3-4): “Accountability is a polysemous concept, with various meanings and uses in many areas, such as administration, economics, and politics. [...] A comprehensive concept, accountability is an integral part of any procedural definition of democracy (SCHMITTER, 1999), as it encompasses two articulated and fundamental elements for this regime: accountability and responsiveness of political actors. The first is directly related to the availability of information about the acts practiced by the agents that operate in the state sphere. It is related, therefore, to the instruments of greater or lesser transparency of government. Responsiveness, in turn, means that the preferences of the constituents are effectively considered in the work of those who hold positions in the state bureaucracy. Accountable agencies, institutions and governments are therefore transparent and responsive to society and citizens"; sul concetto di accountability si vedano anche: R. W. Grant e R. Keohane (2005); D. Held (2004); R. Keohane (2003); J. Nye Jr. (2001). 
Dal momento che, per le specifiche caratteristiche che contraddistinguono le organizzazioni internazionali, i tipici riferimenti alle forme di accountability orizzontali e verticali ${ }^{45}$ non sono sufficienti, essa pare doversi ricollegare al concetto, proposto dalla dottrina, di "social" accountability $^{46}$, intesa come una forma di controllo sociale esercitato al di fuori della sfera statale da attori della società civile e dai media, le cui conseguenze possono essere anche molto gravi per le organizzazioni internazionali. Nonostante questo approccio possa sembrare mite, poiché evidentemente meno strutturato di quello connesso alla valutazione della accountability orizzontale o verticale, in realtà, tenuto conto dei soggetti giuridici cui si rivolge, che si muovono su un piano diverso da quello statale e sono costituiti consensualmente dagli Stati per il perseguimento di fini di interesse comune, può essere vincente.

Se è vero, infatti, che le organizzazioni internazionali non sono democraticamente legittimate e operano in un contesto giuridico in cui è impossibile identificare un sistema giuridico universale e ancora meno un'istituzione di governo mondiale capace di sanzionarle, nel rapporto con l’opinione pubblica la loro posizione è sostanzialmente fragile: messe di fronte ad una questione di "social" accountability, potrebbero trovarsi a fronteggiare delle accuse che danneggiano la loro reputazione e, come effetto a cascata, determinano un'esponenziale perdita di influenza e di prestigio che potrebbe determinare, nei casi più gravi, persino la totale inefficacia dell’azione dell'organizzazione ${ }^{47}$.

45 A. E. Pereira, R. R. Horochovski, M. Mattos de Almeida Cruz e N. Rodrigues (2017, p. 4): "horizontal accountability is constituted by the controls that agencies of the three branches of government - legislative, executive and judicial exercise on each other. Of course, the effectiveness of these controls is a function of the symmetry of power and of the relative autonomy of each of these branches in relation to the other two. [...] Vertical accountability is exercised by the constituents over the incumbents, by the voters over the elected. Its main mechanism is, therefore, the elections.”

46 In questo senso: C. Smulovitz e E. Peruzzotti (2000).

47 Cfr. S. Burall, C. Neligan (2005, p. 5): “As the responsibilities of international organizations (IGOs) have multiplied, so have calls for greater responsiveness and accountability. [...] Accordingly, IGOs must ensure the participation of internal and external stakeholders, including civil society and government. They must be transparent, both in disclosing information and in their decision-making processes.” Peraltro, come sintetizzato efficacemente dagli stessi autori: "[...] the transparency dimension of accountability is, at the level of principle at least, the easiest to develop broader political pressure for as there is general acceptance that access to timey, relevant information about an organization's activities and policies is vital to ensure that both internal and external stakeholders are able to hold an organization to account effectively. It is worth pointing out, though, that there is a difference between access to information (providing access to agendas, policy papers and other key documents) and broader transparency (providing access to decision-making processes themselves). The debate about this dimension normally begins at the level of what information should be made available to stakeholders and what information would not be in the public good (because it is market sensitive, is based on secret intelligence in relation to peace and security etc.). What makes these debates so important is that movement towards greater transparency may be the first step towards broader organizational reform. As these reforms will often require a shifting in the balance of power, there is the possibility of some actors within IGOs resisting transparency reforms as the first line defense.” (BURALL; NELIGAN, 2005, p. 15). Per un approfondimento sull'accountability e la trasparenza nelle organizzazioni internazionali si vedano anche: M. Ecker-Ehrhardt (2018a); M. Ecker-Ehrhardt (2018b); J. Tallberg, T. Sommerer e T. Squatrito (2014); M. Parizek e M. Stephen (2021); J. Tallberg e M. Zürn (2019); P. Schleifer, M. Fiorini e G. Auld (2019); A. Grigorescu (2007). 
In conclusione, quindi, è importante sottolineare che, nonostante l'assetto normativo finale dei diversi ordinamenti sia sostanzialmente lo stesso, la motivazione che spinge gli attori istituzionali ad elaborare politiche normative parzialmente analoghe non è del tutto identica, poiché si fonda su ragionamenti ed argomentazioni non assimilabili. La formulazione delle norme interne che sanciscono gli obblighi di riservatezza nella maggior parte delle organizzazioni internazionali deve essere considerata un indizio utile a mettere in evidenza come, in realtà, l'obiettivo principale perseguito riguarda la tutela della buona immagine dell'organizzazione, della sua credibilità esterna, nonché della sua capacità di mediare tra le istanze nazionali, piuttosto che quello di garantire l’imparzialità e il buon andamento delle strutture organizzative ${ }^{48}$.

\section{BIBLIOGRAFIA}

ABBAMONTE, G. La funzione amministrativa tra riservatezza e trasparenza. Introduzione al tema. 35 Convegno di studi di scienza dell’amministrazione. Varenna, Italy, 1989. In:

L'amministrazione pubblica tra riservatezza e trasparenza. Atti del XXXV Convegno di studi di scienza dell'amministrazione. Milano: Giuffre, 1991. p. 7 et seq.

AGO, R. L’organizzazione internazionale dalla Società delle Nazioni alle Nazioni Unite. La Comunità internazionale, [s. l.], v. I, n. 1, p. 5-23, 1946.

AKEHURST, M. B. Unilateral Amendment of condition of employment in international organizations. In: The British Yearbook of International Law. London: Oxford University Press, 1964.

ANZON, A. Segreto. In: Treccani Enciclopedia Giuridica. Roma: Treccani, 2010. p. 5.

ARENA, G. Trasparenza amministrativa. In: CASSESE, S. (Ed.). Dizionario di diritto pubblico. V. VI. Milano: Giuffrè, 2006.

ARENA, G.; CORSO, G.; GARDINI, G.; MARZUOLI, C; MERLONI, F. (Ed.). La trasparenza amministrativa. Milano: Giuffrè, 2008.

AVANZINI, G.; MATUCCI, G. (Ed.). L’informazione e le sue regole. Libertà, pluralismo e trasparenza. Napoli: Editoriale Scientifica, 2016.

BASTID-BASDEVANT, S. La nature réglementaire ou contractuelle du lien des fonctionnaires des Institutiones des Communautés Européennes. Rivista di diritto europeo, Milano, p. 135-148, avriljuin 1964.

48 Aspetti che assumono senza dubbio un rilievo giuridico anche nel contesto organizzativo internazionale, ma da considerare in ogni caso secondari nella configurazione della disciplina interna complessiva. 
BASTID-BASDEVANT, S. Le droit appliqué par les tribunaux administratifs internationaux. In: Collected Courses of the Hague Academy of International Law. V. 92. Leiden: Martinus Nijhoff, 1957. p. 129-147.

BATTINI, S. L’impatto della globalizzazione sulla pubblica amministrazione e sul diritto amministrativo: quattro percorsi. Giornale di diritto amministrativo, [s. l.], n. 3, p. 339-343, 2006.

BEDJAOUI, M. Fonction publique internationale et Influences nationales. Londra: Stevens, 1958.

BENVENUTI, F. Il nuovo cittadino. Tra libertà garantita e libertà attiva. Venezia: Marsilio, 1994.

BOBBIO, N. La democrazia e il potere invisibile. Rivista trimestrale di scienze politiche, [s. l.], v. 10, n. 2, p. 181-203, 1980.

BURALL, S.; NELIGAN, C. The accountability of international organizations. In: GPPi Research Paper Series No. 2, 23 p. Berlin: Global Public Policy Institute, 2005.

CALIFANO, L.; COLAPIETRO, C. Le nuove frontiere della trasparenza nella dimensione costituzionale. Napoli: Editoriale scientifica, 2014.

CANSACCHI, G. Il contratto di impiego dei dipendenti di enti internazionali. Il Diritto dell'economia, [s. l.], p. 133 et seq., 1955.

CAPOTORTI, F. Sulla competenza a stipulare degli organi di Unioni. In: Scritti di diritto internazionale in onore di T. Perassi. V. I. Milano: Giuffrè, 1957. p. 284 et seq.

CARINGELLA, F. Manuale di diritto amministrativo. 10. ed. Roma: Dike, 2016.

CARLSTON, K. S. International Administrative Law: A Venture in Legal Theory. Journal of Public Law, [Atlanta], v. 8, n. 2, p. 329-380, 1959.

CASETTA, E. Manuale di diritto amministrativo. 18. ed. Milano: Giuffrè, 2016.

CASSESE, S. Relations between International Organizations and National Administrations. In: International Institute of Administrative Sciences, Proceedings of the XIXth International Congress of Administrative Sciences. London: Kluwer Law and Taxation Publishers, p. 161 et seq., 1983.

CAVALLARO, M. C. Garanzie della trasparenza amministrativa e tutela dei privati. Diritto Amministrativo, [s. l.], n. 1, p. 121-148, 2015.

CHIEPPA, R.; GIOVAGNOLI, R. Manuale di diritto amministrativo. Milano: Giuffrè, 2018.

CLARICH, M. Manuale di diritto amministrativo. 3. ed. Bologna: il Mulino, 2017.

COMBA, A. Le giurisdizioni amministrative delle organizzazioni internazionali, Torino: G. Giappichelli, 1967. 
CONTIERI, A. Trasparenza e diritto di accesso dei cittadini: agli atti e alle informazioni pubbliche. In: KOZICKI, K.; CHUEIRI, V. K.; IMMORDINO, M. (Coord.). Direito Comparado. Diálogos de Direito Constitucional e Administrativo entre Brasil e Itália. Curitiba: Instituto Memória, 2018. p. 149-167.

CORSO, G. Manuale di diritto amministrativo. 8. ed. Torino: G. Giappichelli, 2017.

COSTANTINO, F. Postilla di aggiornamento. Segreto: VI) Segreto d'ufficio - dir. Amm. In: Treccani Enciclopedia Giuridica. Roma: Treccani, 2010. p. 1-4.

CUCCINIELLO, M. V.; PORUMBESCU, G. A.; GRIMMELIKHUIJSEN, S. 25 Years of Transparency Research: Evidence and Future Directions. Public Administration Review, [s. l.], v. 77, n. 1, p. 32-44, 2017.

CURTIN, D.; MENDES, J. Transparence et participation: des principes démocratiques pour l'administration de l'Union Européenne. Revue française d'administration publique, [s. l], n. 137-138, p. 101-121, 2011.

DANZA, M. D.Lgs. 30 marzo 2001 n.165. IL TESTO UNICO SUL PUBBLICO IMPIEGO

“Norme generali sull'ordinamento del lavoro alle dipendenze delle amministrazioni pubbliche”. 8. ed. Roma: Università Popolare di Roma per gli studi Giuridici Economici e Sindacali, 2017.

DELL'ARINGA, C.; DELLA ROCCA, G. (Ed.). Lavoro pubblico fuori dal tunnel? Retribuzioni, produttività, organizzazione. Bologna: il Mulino, 2017.

ECKER-EHRHARDT, M. International Organizations “Going Public”? An Event History Analysis of Public Communication Reforms 1950-2015. International Studies Quarterly, [s. l.], n. 4, p. 723-736, 2018b.

ECKER-EHRHARDT, M. Self-legitimation in the face of politicization: Why international organizations centralized public communication. The Review of International Organizations, [s. l.], v. 13, n. 4, p. 519-546, 2018 .

ESPOSITO, M.; LUCIANI, V.; ZOPPOLI, A.; ZOPPOLI, L. La riforma dei rapporti di lavoro nelle pubbliche amministrazioni. Commento alle innovazioni della XVII legislatura (2013-2018) con particolare riferimento ai d.lgs. nn. 74 e 75 del 25 maggio 2017 (c.d. riforma Madia). Torino: G. Giappichelli, 2018.

ESTY, D. C. Good Governance at the Supranational Scale: Globalizing Administrative Law. The Yale Law Journal, [s. l.], v. 115, p. 1.490-1.563, 2006.

FEDERATION OF INTERNATIONAL CIVIL SERVANTS' ASSOCIATIONS (FICSA). FICSA Council. FICSA/C/57/PSA/4. 57th Session WMO, Geneva, 2 to 7 February, 2004.

FLOGAITIS, S. I principi generali del diritto nella giurisprudenza del Tribunale Amministrativo delle Nazioni Unite. In: D’ALBERTI, M. (Ed.). Le nuove mete del diritto amministrativo. Bologna: il Mulino, 2010.

FOCARELLI, C. Diritto internazionale. 3. ed. Padova: Cedam, 2015. 
FOCCILLO, A. Il rapporto di lavoro nel pubblico impiego. Evoluzione e commento. 2. ed. Roma: Aracne, 2018.

FREEDLAND, M. Government by Contract Re-examined. Some Functional Issues. In: CRAIG, P.; RAWLINGS, R. (Ed.). Law and Administration in Europe. Essays in Honour of Carol Harlow. Oxford: Oxford University Press, 2003. p. 123-138.

GALLO, D. Status, privilegi, immunità e tutela giurisdizionale dei funzionari delle organizzazioni internazionali. In: DEL VECCHIO, A. (Ed.). Diritto delle Organizzazioni Internazionali. Napoli: Edizioni Scientifiche Italiane, 2012. p. 273-314.

GARDINI, G. La transparencia administrativa: ¿derecho fundamental o instrumento de lucha contra la corrupción? Un estudio comparado de los regímenes italiano y español. In: HUERGO LORA, A. (Coord.). Nuevas perspectivas en la defensa de los ciudadanos frente a las Administraciones Públicas. Madrid: Iustel, 2018. p. 21-52.

GAROFOLI, R.; FERRARI, G. Manuale di diritto amministrativo. 12. ed. Roma: Nel Diritto, 2018.

GRANT, R. W.; KEOHANE, R. Accountability and abuses of power in world politics. The American Political Science Review, [s. l.], v. 99, n. 1, p. 29-43, 2005.

GRIGORESCU, A. Transparency of Intergovernmental Organizations: The Roles of Member States, International Bureaucracies and Nongovernmental Organizations. International Studies Quarterly, [s. l.], v. 51, n. 3, p. 625-648, 2007.

HELD, D. Democratic Accountability and Political Effectiveness from a Cosmopolitan Perspective. Government and Opposition, [s. l.], v. 39, n. 2, p. 364-391, 2004.

HOOD, C.; HEALD, D. (Ed.). Transparency: The Key to Better Governance? Oxford: Oxford University Press, 2006.

HUDSON, M. O. Progress in International Organization. Oxford: Oxford University Press, 1932.

INTERNATIONAL LABOUR OFFICE. Principles of Conduct for Staff of the International Labour Office. Office of the Ethics Officer. Geneva: International Labour Office, 2009.

INTERNATIONAL LABOUR OFFICE. Staff Regulations. [Geneva]: International Labour Office, 2020.

IRELLI, V. C. Lineamenti del diritto amministrativo. 5. ed. Torino: G. Giappichelli, 2016.

KEOHANE, R. Global governance and democratic accountability. In: HELD, D.; KOENIGARCHIBUGI, M. (Ed.). Taming globalization: frontiers of governance, Cambridge: Cambridge: Polity Press, 2003. p. 130-159. 
KINGSBURY, B.; CASINI, L. Global Administrative Law Dimensions of International Organizations Law. IILJ Working Paper 2009/9 (Global Administrative Law Series). New York: New York University School of Law, 2009. 29 p.

LATHROP, D.; RUMA, L. (Ed.). Open Government. Collaboration, Transparency and Participation in Practice. Sebastopol: O’Reilly, 2010.

LAZZARO, A. Trasparenza e prevenzione della cattiva amministrazione. Milano: Giuffrè, 2017.

LEMOINE, J. Le contrôle judiciaire des modifications des conditions de service des fonctionnaires internationaux. Annuaire français de droit international, [s. l.], v. 8, p. 407-426, 1962.

LEMOINE, J., Jurisprudence du Tribunal administratif de l'Organisation internationale du travail. Annuaire français de droit international, [s. l.], v. 14, p. 304-321, 1968.

MANGANARO, F. L'evoluzione del principio di trasparenza. In: SCOCA, F. G. (Ed.). Scritti in memoria di Roberto Marrama. Napoli: Editoriale scientifica, 2012. p. 639 et seq.

MARRAMA, R. La pubblica amministrazione tra trasparenza e riservatezza nell'organizzazione e nel procedimento amministrativo. $35^{\circ}$ Convegno di studi di scienza dell'amministrazione. Varenna, Italy, 1989. In: L'amministrazione pubblica tra riservatezza e trasparenza. Atti del XXXV Convegno di studi di scienza dell’amministrazione. Milano: Giuffre, 1991. p. 53-88.

MATTARELLA, B. G. I doveri di comportamento dei dipendenti pubblici. In: MERLONI, F.; VANDELLI, L. (Ed.). La corruzione amministrativa. Cause, prevenzione e rimedi. Firenze: Passigli, 2010.

MEIJER, A. Transparency. In: BOVENS, M.; GOODIN, R. E.; SCHILLEMANS, T. (Ed.). Oxford Handbook of Public Accountability. Oxford: Oxford University Press, 2013.

MEIJER, A. Understanding modern transparency. International Review of Administrative Sciences, [s. l.], v. 75, n. 2, p. 255-269, 2009.

MEIJER, A.; 'T HART, P.; WORTHY, B. Assessing government transparency: an interpretive framework. Administration \& Society, [s. l.], v. 50, n. 4, p. 501-526, 2018.

MIR PUIGPELAT, O. Transparencia y procedimiento administrativo. El derecho de acceso al expediente y su conexión con el derecho de acceso a información pública. Madrid: Civitas, 2019.

MONACO, R. R. Lezioni di organizzazione internazionale. Vol. 1: Principi generali. Torino: G. Giappichelli, 1985.

NAZIONI UNITE. Carta delle Nazioni Unite. Adottata a S. Francisco il 26 giugno 1945, entrata in vigore con il deposito del ventinovesimo strumento di ratifica il 24 ottobre 1945. Ratificata dall'ltalia con legge 17 agosto 1957 n. 848 in Suppl. Ord. G.U. n. 238 del 25 settembre 1957. [New York]: Nazioni Unite, 1945. 
NYE JR., J. Globalization's Democratic Deficit. How to Make International Institutions More Accountable. Foreign Affairs, [s. l.], v. 80, n. 4, p. 2-6, 2001.

OPPENHEIM, L. Le caractère essentiel de la Société des Nations. Revue générale de droit international public, [s. l.], n. 26, p. 234-244, 1919.

PARIZEK, M.; STEPHEN, M. The Increasing Representativeness of International Organizations' Secretariats: Evidence from the United Nations System, 1997-2015. International Studies Quarterly, [s. l.], v. 65, n. 1, p. 197-209, March 2021.

PASQUIER, M. Le principe de transparence: en Suisse et dans le monde. Losanna: EPFL, 2013.

PEREIRA, A. E.; HOROCHOVSKI, R. R.; CRUZ, M. M. A.; RODRIGUES, N. Accountability in International Organizations: the case of World Bank Inspection Panel (1993-2015). Bras. Political Sci. Rev., [s. l.], v. 11, n. 1, 28 p., 2017.

PINTOS SANTIAGO, J. (Dir.). Calidad, transparencia y ética pública. Madrid: Instituto Nacional de Administración Pública, 2017.

PLANTEY, A.; LORIOT, F. Fonction publique internationale. Organisations mondiales et européennes. Parigi: CNRS, 2016.

QUADRI, G. Riservatezza e trasparenza nella esperienza costituzionale. $35^{\circ}$ Convegno di studi di scienza dell'amministrazione. Varenna, Italy, 1989. In: L'amministrazione pubblica tra riservatezza e trasparenza. Atti del XXXV Convegno di studi di scienza dell'amministrazione. Milano: Giuffre, 1991. p. 23 et seq.

RAVERAIRA, M. Segreto nel diritto costituzionale. In: Digesto delle discipline pubblicistiche, vol. XIV. Torino: UTET, 1999. p. 18-30.

SAROOSHI, D. The Role of Domestic Public Law Analogies in the Law of International Organizations. International Organizations Law Review, [s. l.], v. 5, n. 2, p. 237-239, 2008.

SAVINO, M. Il FOIA italiano e i suoi critici: per un dibattito scientifico meno platonico. Diritto Amministrativo, [s. l.], anno XXVII, n. 3, p. 453-495, 2019.

SCHLEIFER, P.; FIORINI, M.; AULD, G. Transparency in transnational governance: The determinants of information disclosure of voluntary sustainability programs. Regulation \& Governance, [s. l.], v. 13, n. 4, p. 488-506, 2019.

SCOCA, F. G. Diritto amministrativo. Torino: G. Giappichelli, 2017.

SILVERSTEIN, R. Revisiting the legal basis to deny international civil servants access to a fundamental human right. Michigan State International Law Review, [s. l.], v. 25, n. 2, p. 375428, 2017.

SIMONATI, A. La ricerca in materia di trasparenza amministrativa: stato dell'arte e prospettive future. Diritto Amministrativo, [s. l.], v. 2, p. 311-336, 2018. 
SMULOVITZ, C.; PERUZZOTTI, E. Societal accountability in Latin America. Journal of Democracy, [s. l.], v. 11, n. 4, p. 147-158, 2000.

SPASIANO, M. R. I principi di pubblicità, trasparenza e imparzialità. In: SANDULLI, M. A. (Ed.). Codice dell'azione amministrativa. Milano: Giuffrè, 2011. p. 84-95.

STARITA, M. Article 2. In: KOLB, R. (Ed.). Commentaire sur le pacte de la Société des Nations. Bruxelles: bruylant, 2015. p. 109-162.

TALLBERG, J.; SOMMERER, T.; SQUATRITO, T. Explaining Patterns in IO Openness: Governance Problems, Policy Approaches, and Institutional Design. Politischen Vierteljahresschrift, [s. l.], v. 49 (Special Issue), p. 370-395, 2014.

TALLBERG, J.; ZÜRN, M. The Legitimacy and Legitimation of International Organizations: Introduction and Framework. The Review of International Organizations, [s. l.], v. 14, n. 4, p. 581-606, 2019.

TENORE, V. Studio sul procedimento disciplinare nel pubblico impiego. Dopo la legge anticorruzione e la riforma Madia (L. 7 agosto 2015 n. 124). Milano: Giuffrè, 2017.

TOSATO, G. L. L'Istituto internazionale per l’unificazione del diritto privato e la giurisdizione italiana. Rivista di Diritto Internazionale, [s. l.], v. 50, p. 150-171, 1967.

UNITED NATIONS. Standards of Conduct for the International Civil Service. International Civil Service Advisory Board. [New York]: United Nations, 2013.

WORLD BANK GROUP. Staff Rule 3.01 - Standards of Professional Conduct. [Washington, DC]: World Bank, 2009. 